\title{
Anion Binding Studies of Fluorinated Expanded Calixpyrroles
}

Jonathan L. Sessler, ${ }^{a *}$ Won-Seob Cho, ${ }^{a}$ Dustin E. Gross, ${ }^{a}$ James A. Shriver, ${ }^{a \#}$ Vincent M. Lynch, ${ }^{a}$ Manuel Marquez,

${ }^{a}$ Department of Chemistry and Biochemistry, 1 University Station-A5300, The University of Texas at Austin, Austin, Texas 78712-0165, USA

${ }^{b}$ Chemical Science and Technology Division, Los Alamos National Laboratory, Los Alamos, NM 87545, USA and I'NEST Group, New Technology Research Department, PMUSA, Richmond, VA 23298, USA

${ }^{\#}$ Current Address: Department of Chemistry, 812 University, Central College, Pella, IA 50219, USA

E-mail: sessler@mail.utexas.edu

\section{Supporting Information}

I. Synthetic Experimental Secion S2

II. Spectral Data $-\mathrm{S} 3$

III. ${ }^{1} \mathrm{H}$ NMR Spectroscopic and ITC Titration Studies $-\mathrm{S} 6$

IV. X-ray Experimental Section S16 


\section{Synthetic Experiments}

All NMR solvents were purchased from Cambridge Isotopes, Inc. Proton NMR spectra were recorded on a $400 \mathrm{MHz}$ Spectrometer. Chemical shifts are reported as $\delta$ in ppm using the residual solvent signal as an internal standard. Low-resolution CI mass and High-resolution CI mass spectra were obtained from University of Texas at Austin mass lab.

\section{Synthesis of Dodecafluorocalix[6]pyrrole (5)}

Acetone (0.55 ml, $7.50 \mathrm{mmol}), 3,4$-difluoro- $1 H$-pyrrole $(2)(0.77 \mathrm{~g}, 7.50 \mathrm{mmol})$ and tetrabutylammonium chloride $(5.85 \mathrm{~g}, 15.00 \mathrm{mmol})$ were dissolved in methanol $(37.5$ $\mathrm{ml}$ ). The reaction flask was then placed in a freezer at $-4{ }^{\circ} \mathrm{C}$ for one hour. After being allowed to cool, methanesulfonic acid $(0.49 \mathrm{ml}, 7.5 \mathrm{mmol})$ was added. Once the addition was complete, the reaction mixture was allowed to stir at $-4{ }^{\circ} \mathrm{C}$ for 6 days. The reaction mixture was diluted immediately with saturated aqueous $\mathrm{Na}_{2} \mathrm{CO}_{3}(200 \mathrm{ml})$ and taken into dichloromethane $(100 \mathrm{ml})$. The resulting organic layer was washed with deionized water $(2 \times 100 \mathrm{ml})$ and dried over anhydrous sodium sulfate. Repeated silica column chromatography (hexanes:acetone, 4:1 increasing to 7:3) allowed for the isolation of compounds, 3 (560 mg, 30\%), 4 (250 mg, 30\%), 7 (150 mg, 15\%), and 5 (180 mg, 20\%). A trace quantity of $\mathbf{6}$ was also observed. Compounds 3,4 , and $\mathbf{7}$ proved identical to the materials obtained using our original procedure. ${ }^{1}$ For compound 5: ${ }^{1} \mathrm{H}$ NMR $(400 \mathrm{MHz}$, DMSO- $d_{6}$ ) $\delta=8.91$ (brs, 6H, NH), $3.32(\mathrm{~s}, 36 \mathrm{H}, \mathrm{CH}) ;{ }^{13} \mathrm{C}$ NMR (125 MHz, DMSO- $d_{6}$ ) $\delta=134.8,115.1,34.5,27.3$; HRMS CI+ calcd for $\mathrm{C}_{42} \mathrm{H}_{43} \mathrm{~N}_{6} \mathrm{~F}_{12}$ 859.33576, found $859.33590(\Delta=0.2 \mathrm{ppm})$ 


\section{Spectral Data}

Figure 1. Proton NMR spectrum of dodecafluorocalix[6]pyrrole (5) in DMSO- $d_{6}$

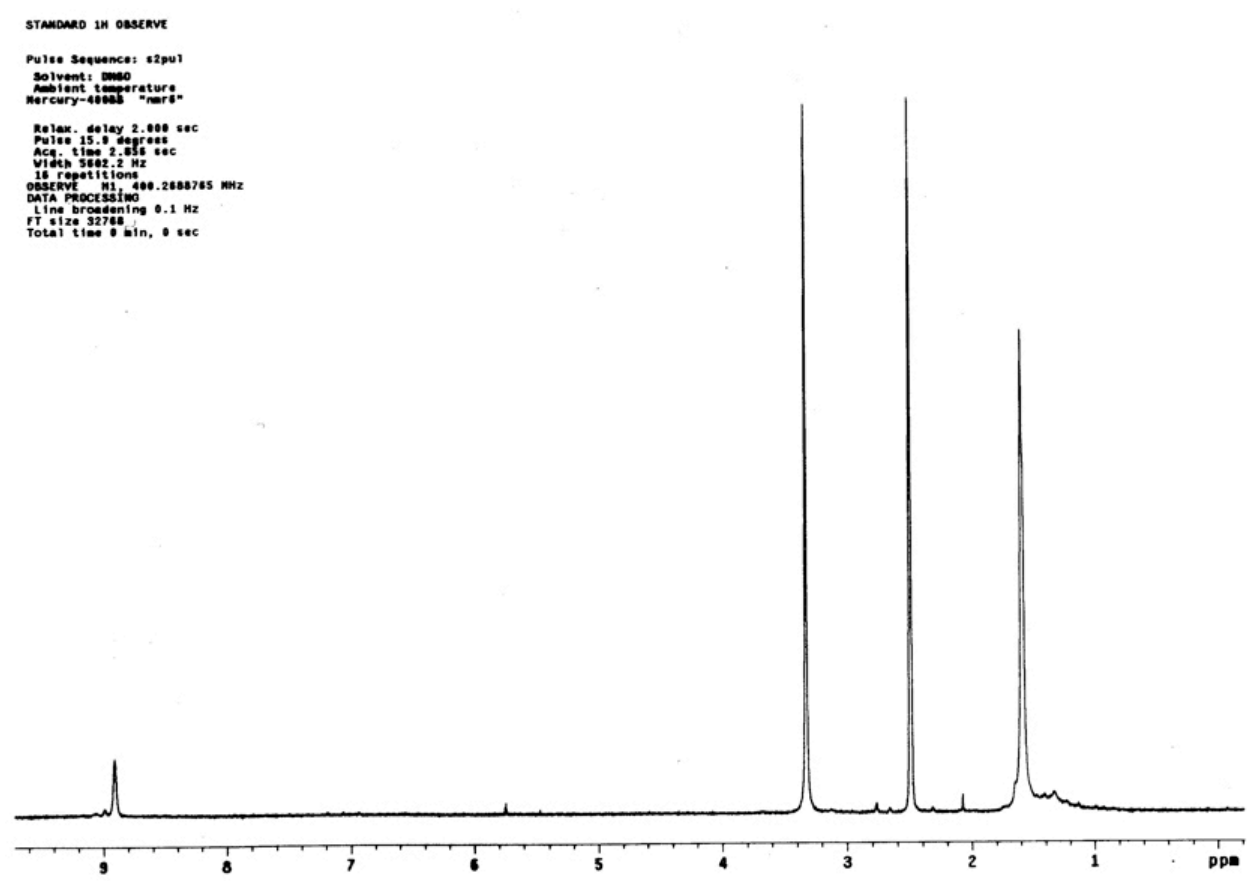

Figure 2. Carbon NMR spectrum of dodecafluorocalix[6]pyrrole (5) in DMSO- $d_{6}$
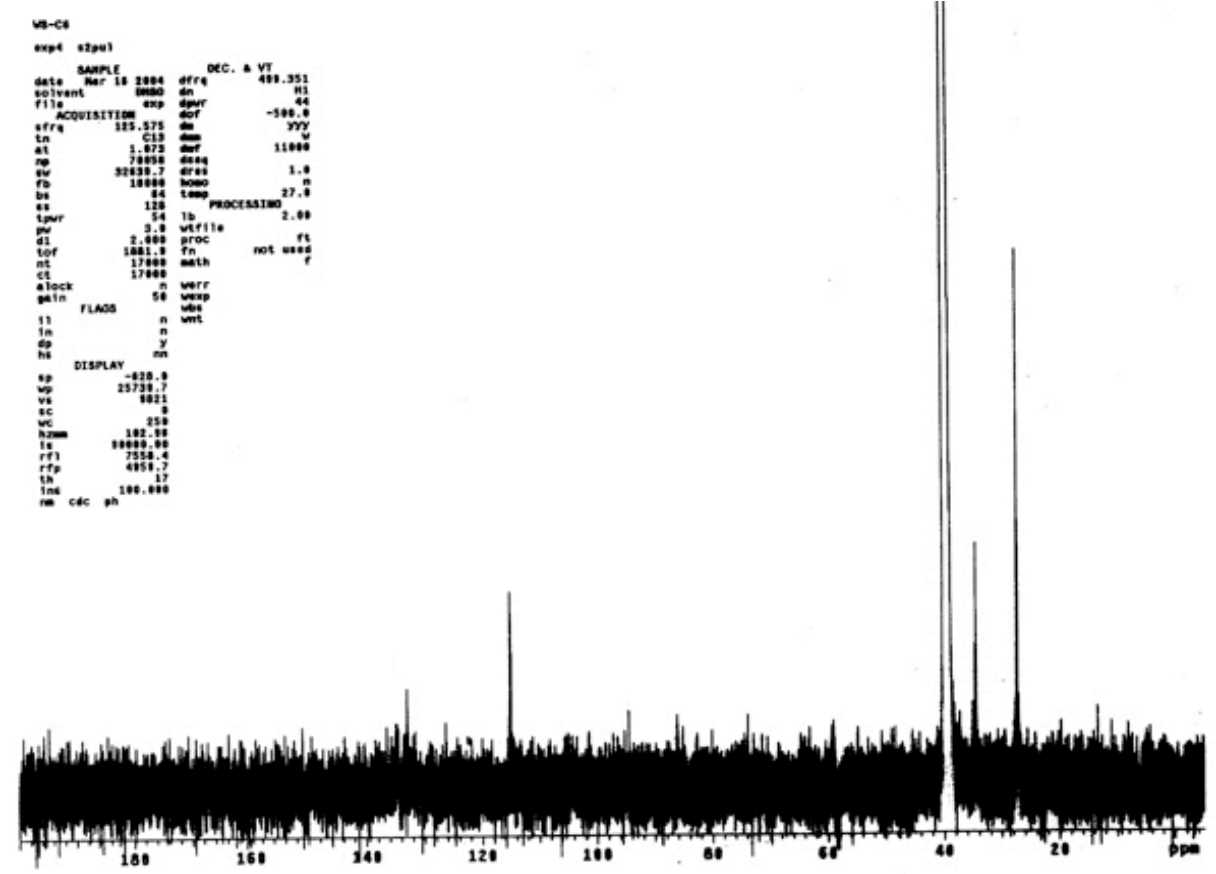
Figure 3. Low resolution CI mass spectrum of dodecafluorocalix[6]pyrrole (5)

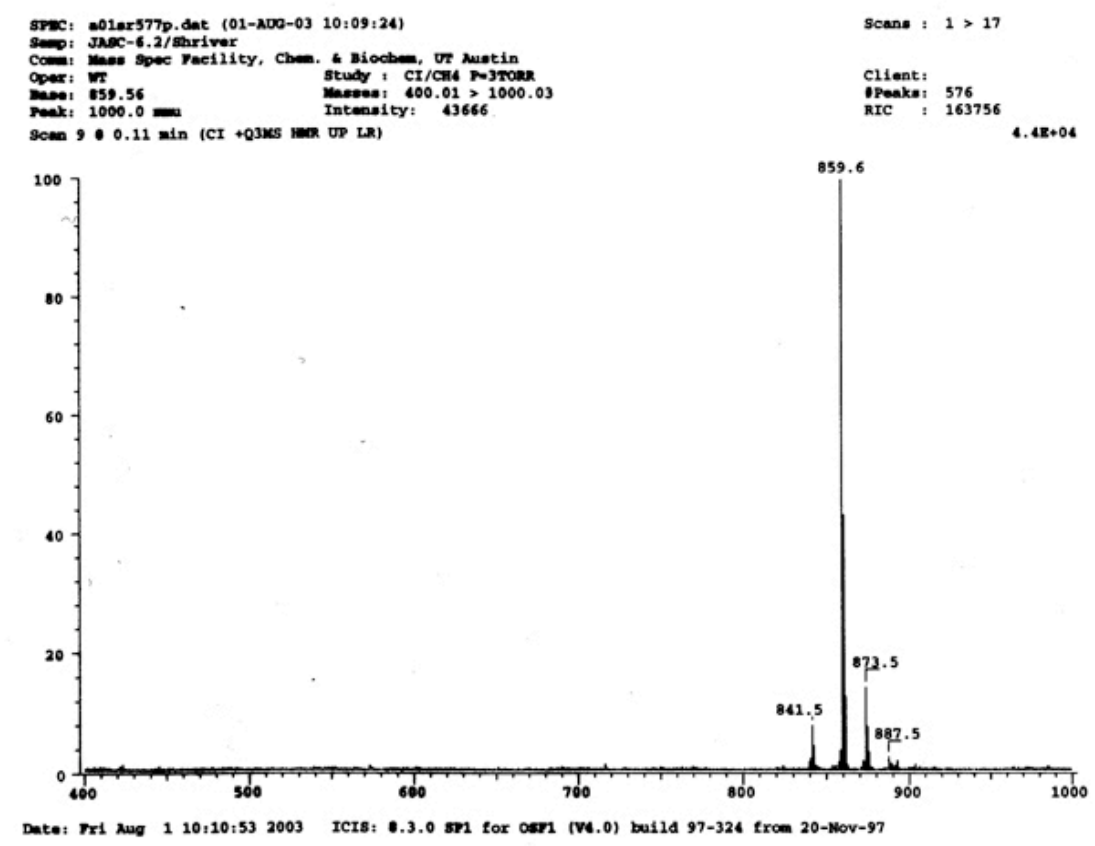

Figure 4. High resolution CI mass spectrum of dodecafluorocalix[6]pyrrole (5)

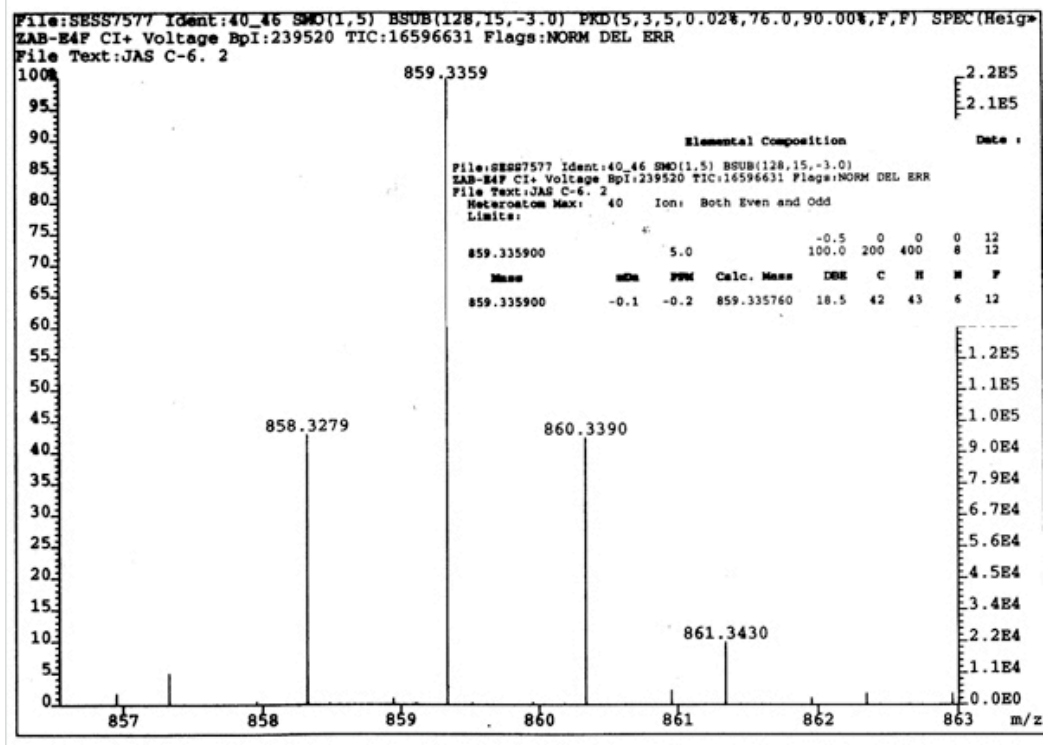


Figure 5. HPLC analysis of crude reaction mixture with internal standard 1,3dibromobenzene

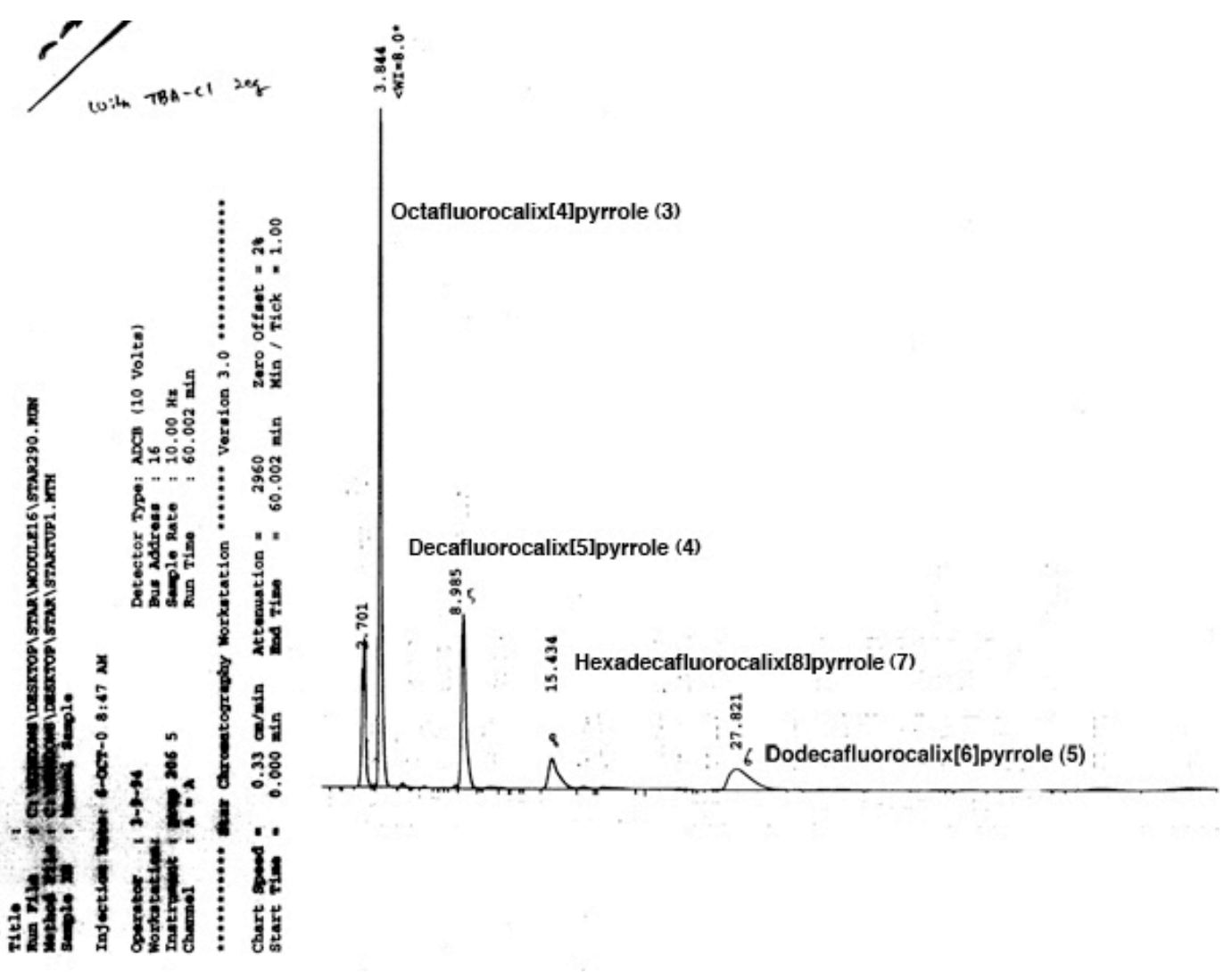




\section{III. ${ }^{1} \mathrm{H}$ NMR Spectroscopic and ITC Titration Studies}

\section{- ${ }^{1}$ H NMR Spectral Titrations}

Proton NMR spectroscopy-based titration studies were carried out using a Varian Unity Plus $400 \mathrm{MHz}$ NMR spectrometer. The receptor solutions were titrated by adding known quantities of a concentrated solution of the anions in question. The anion solutions used to effect the titration contained the receptors at the same concentration as the receptor solutions into which they were being titrated so as to obviate a need to account for dilution effects during the titrations. The data were fit to a 1:1 binding profile according to the method of Wilcox ${ }^{2}$ using the changes in the pyrrolic $\mathrm{NH}$ resonances in the ${ }^{1} \mathrm{H}$ NMR spectra. All tetrabutylammonium anion salts for NMR and ITC titration were purchased from Fluka, Inc., and dried under vacuum oven for $12 \mathrm{hrs}$ at $40{ }^{\circ} \mathrm{C}$ before being used in the titration experiments.

Figure 6. Octamethylcalix[4]pyrrole (1) $+\mathrm{TBA}-\mathrm{Cl}$ in $\mathrm{CD}_{3} \mathrm{CN}\left(2 \% \mathrm{D}_{2} \mathrm{O}\right.$ v/v $)$
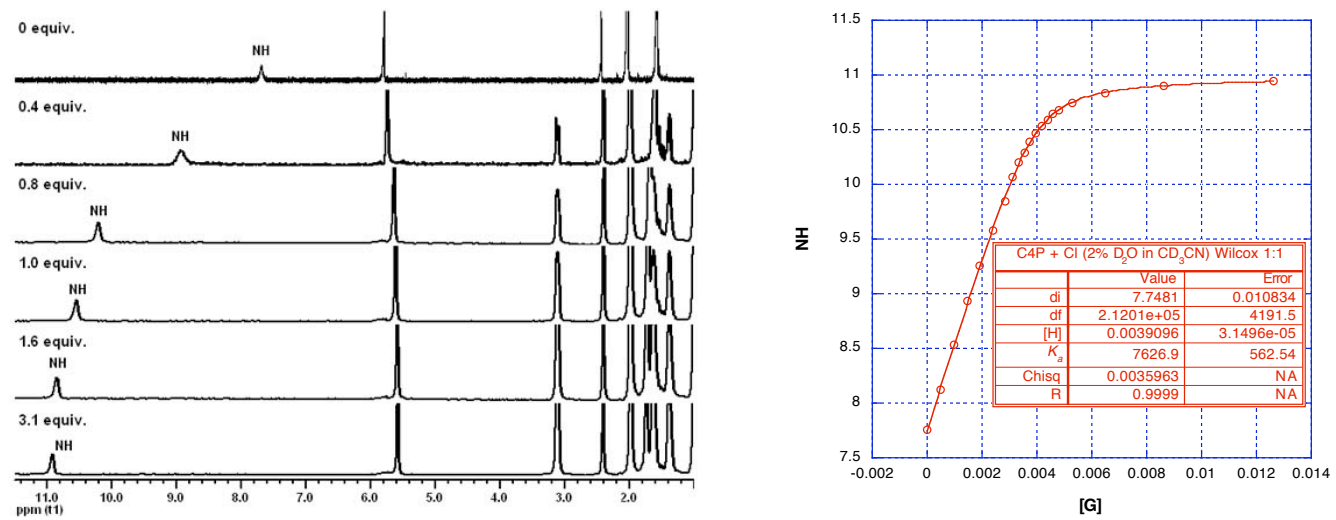

Figure 7. Octafluorocalix[4]pyrrole (3) + TBA-Cl in $\mathrm{CD}_{3} \mathrm{CN}\left(2 \% \mathrm{D}_{2} \mathrm{O}\right.$ v/v)
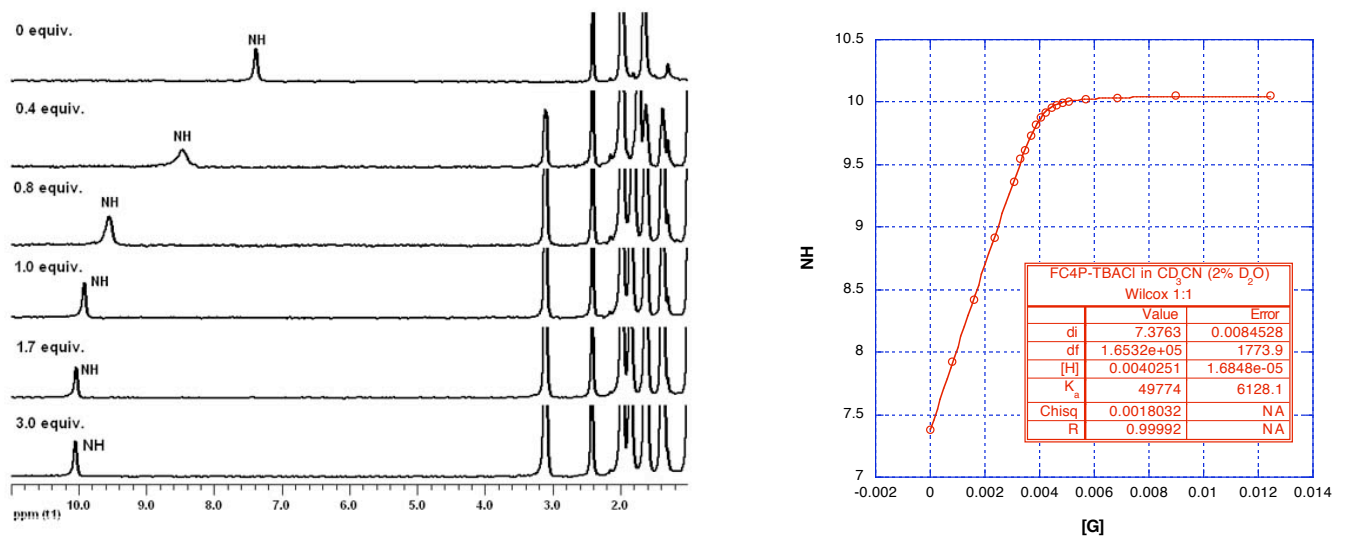


\section{- ITC Titration Plot}

Microcalorimetric titrations (experimental temperature: $30{ }^{\circ} \mathrm{C}$ unless otherwise indicated) were performed using an isothermal titration calorimeter (ITC). The ORIGIN software provided by Microcal Inc. was used to calculate the binding constant $\left(K_{a}\right)$ and the enthalpy change $(\Delta H)$. The solvents, $\mathrm{CH}_{3} \mathrm{CN}$ and DMSO, were purchased from Fisher but was not further dried or purified before use.

Figure 8. ITC plots of octamethylcalix[4]pyrrole (1) and octafluorocalix[4]pyrrole (3) titrated with TBA-chloride in acetonitrile $(2 \% v / v$ water $)$ at $22{ }^{\circ} \mathrm{C}$

Titration with 1 with TBA-Cl

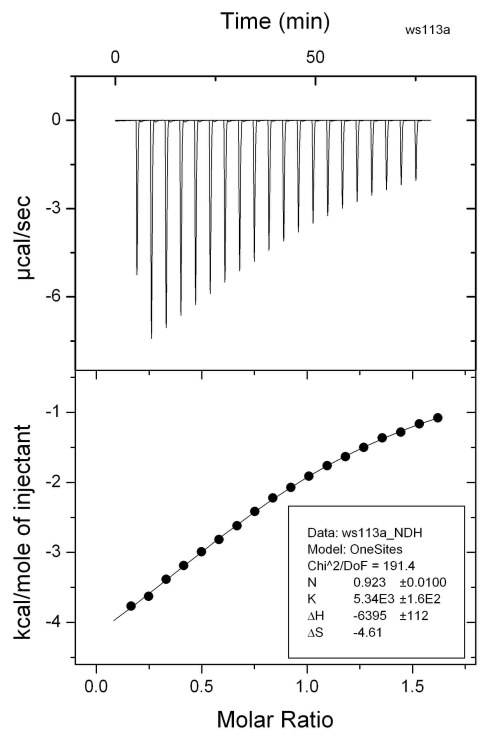

Titration with 3 with TBA-Cl

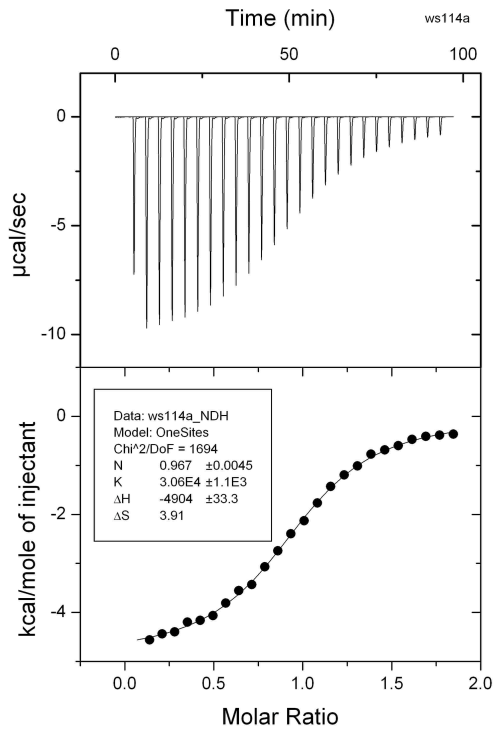


Figure 9. ITC plots of octamethylcalix[4]pyrrole (1) titrated with several anions (TBA salts) at $30^{\circ} \mathrm{C}$

$\underline{\text { Reverse Titration with TBA-acetate in } \mathrm{CH}_{3} \mathrm{CN}}$

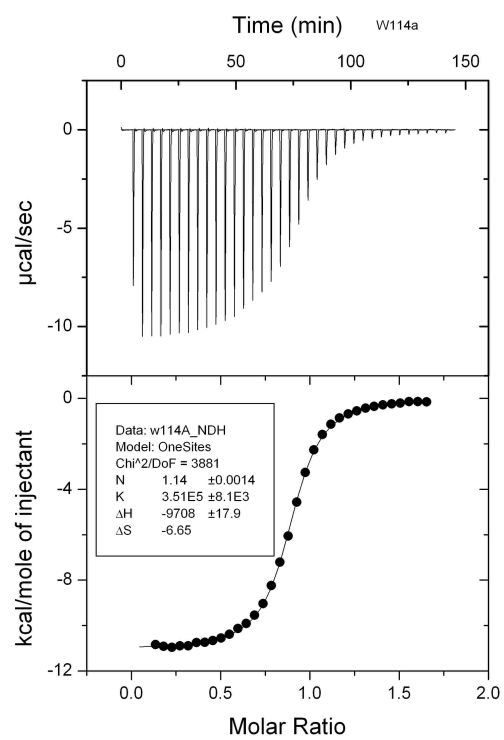

Titration with TBA- $\mathrm{H}_{2} \underline{P O}_{4}$ in DMSO

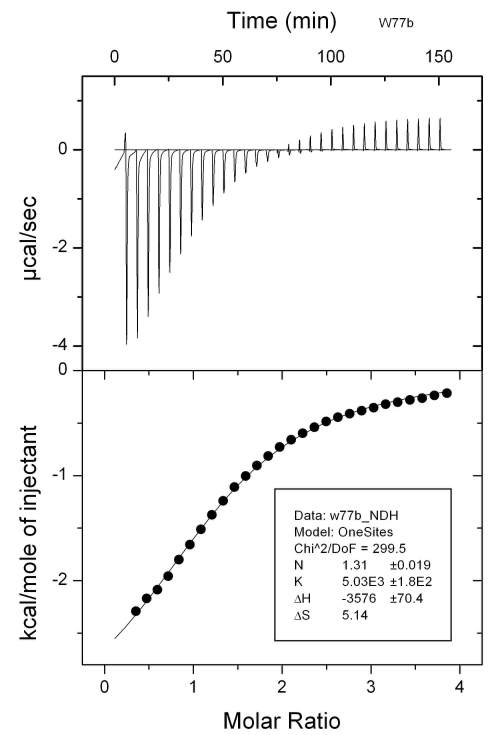

Reverse Titration with TBA-benzoate in $\mathrm{CH}_{3} \mathrm{CN}$

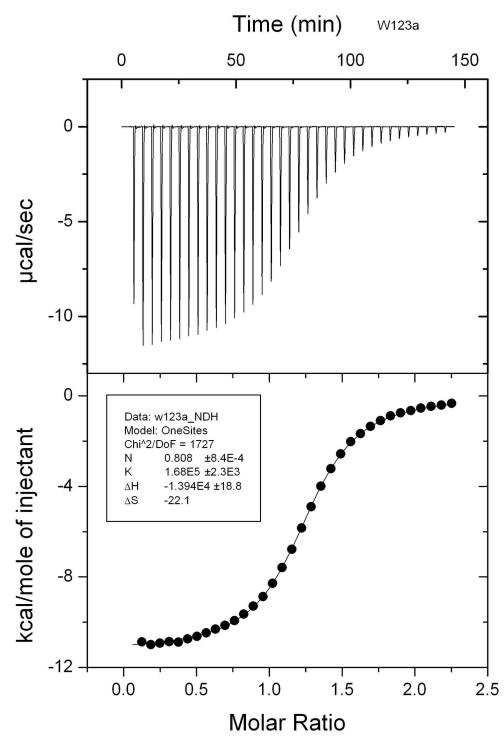

Titration with TBA-acetate in DMSO

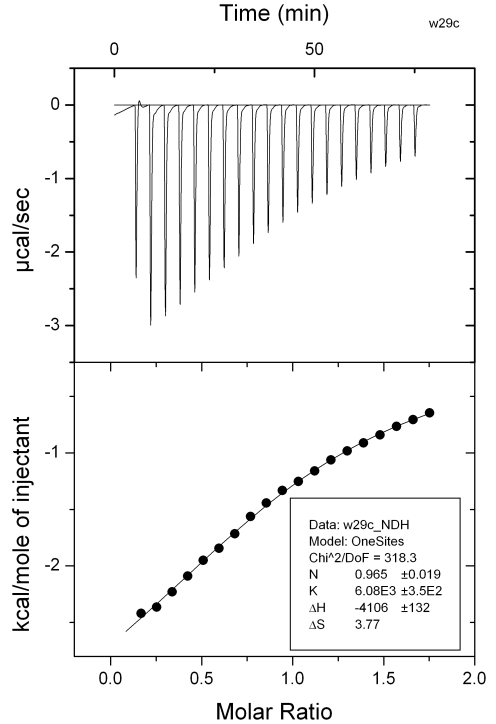


Figure 10. ITC plots of octafluorocalix[4]pyrrole (3) titrated with several anions (TBA salts) at $30{ }^{\circ} \mathrm{C}$

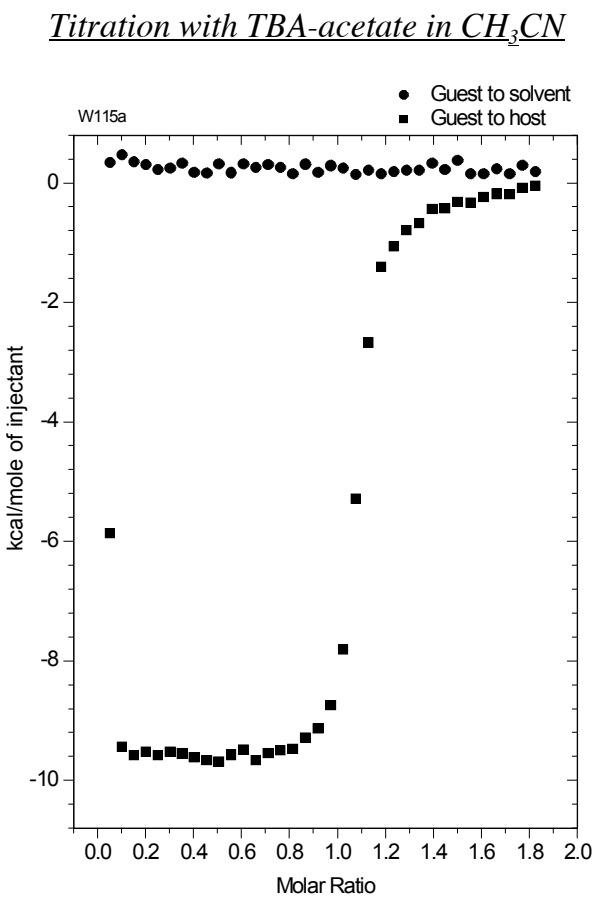

$\underline{\text { Reverse Titration with TBA-acetate in } \mathrm{CH}_{3}}{ }_{3} \underline{\mathrm{CN}}$
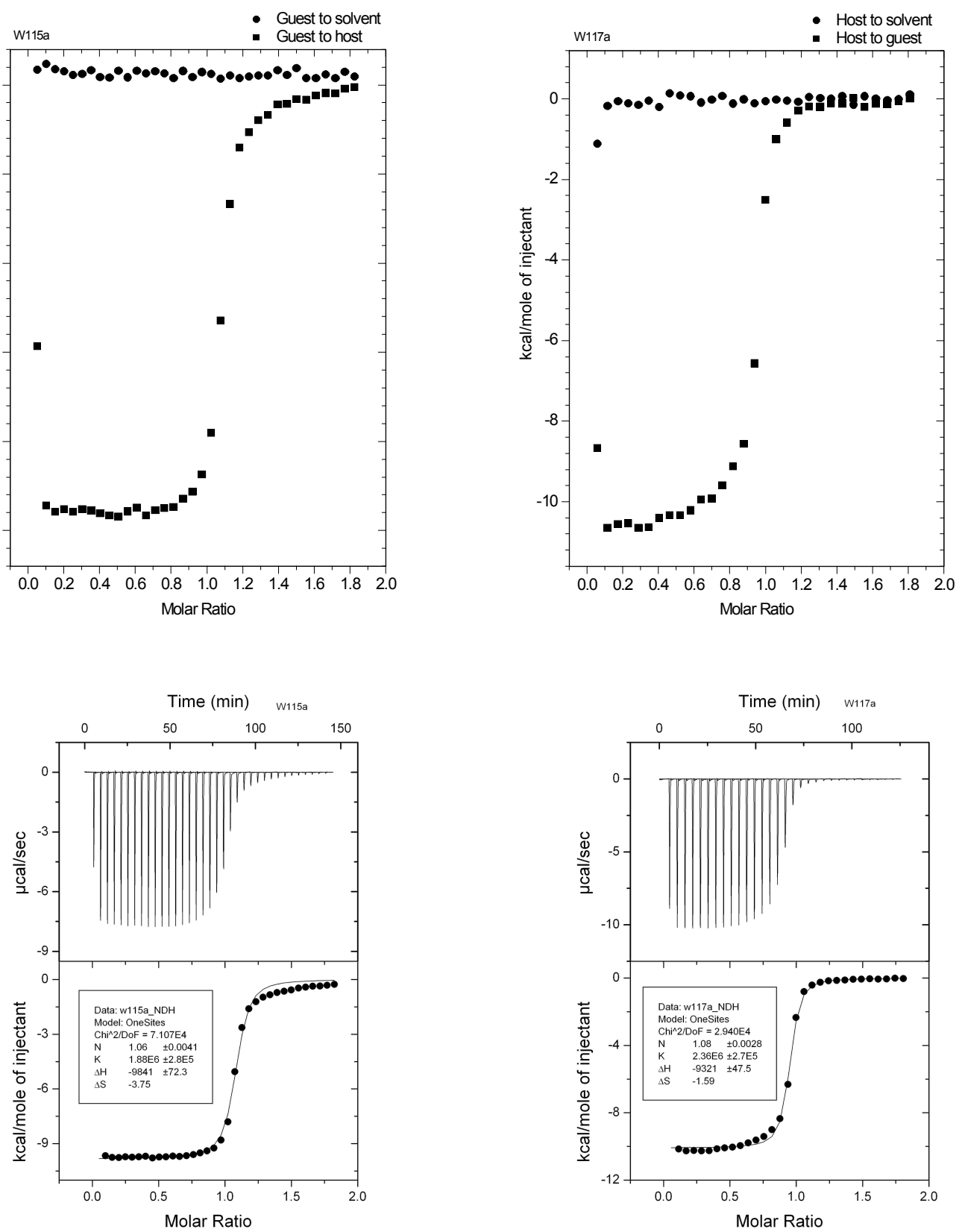
Titration with TBA-benzoate in $\mathrm{CH}_{3} \underline{\mathrm{CN}}$

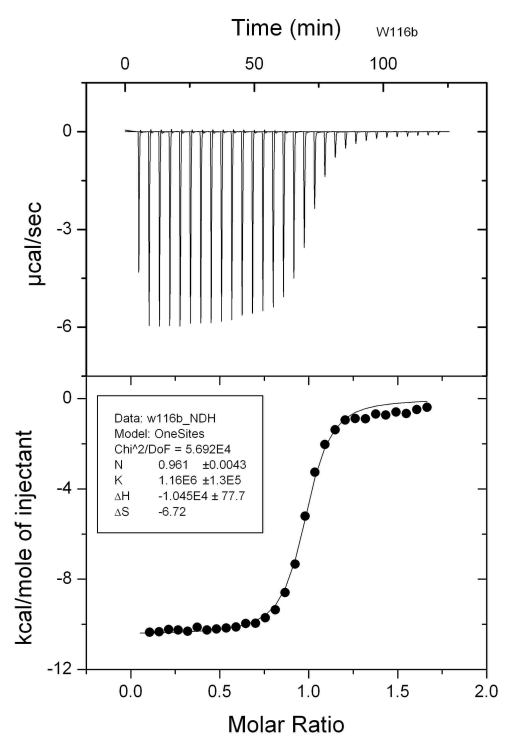

Reverse Titration with TBA-benzoate in $\mathrm{CH}_{3} \underline{\mathrm{CN}}$

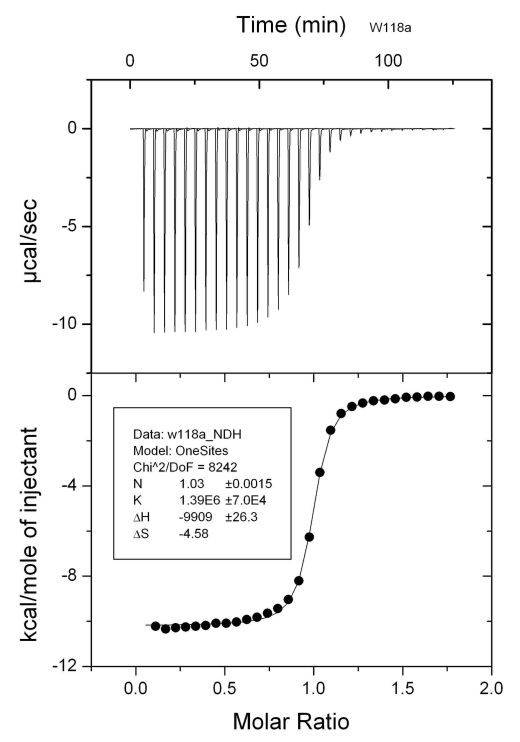



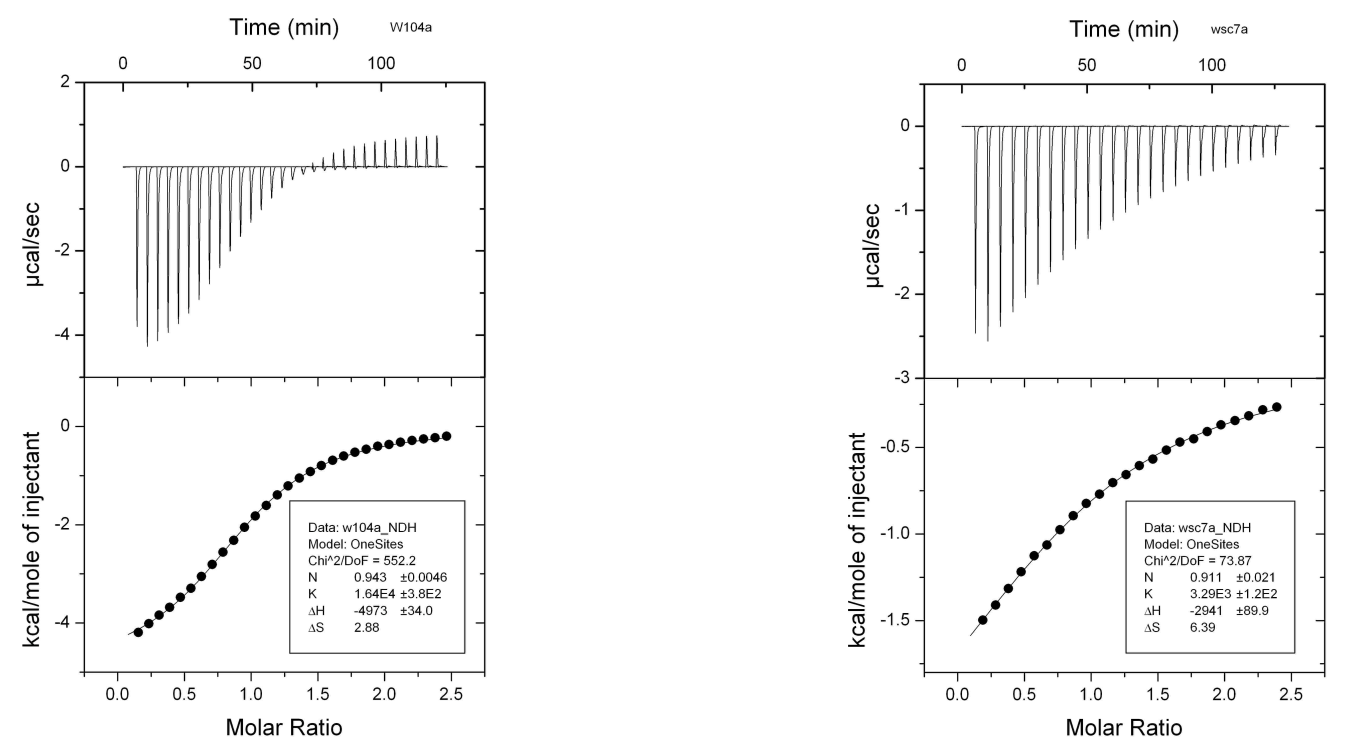

$\underline{\text { Titration with TBA-acetate in DMSO }}$

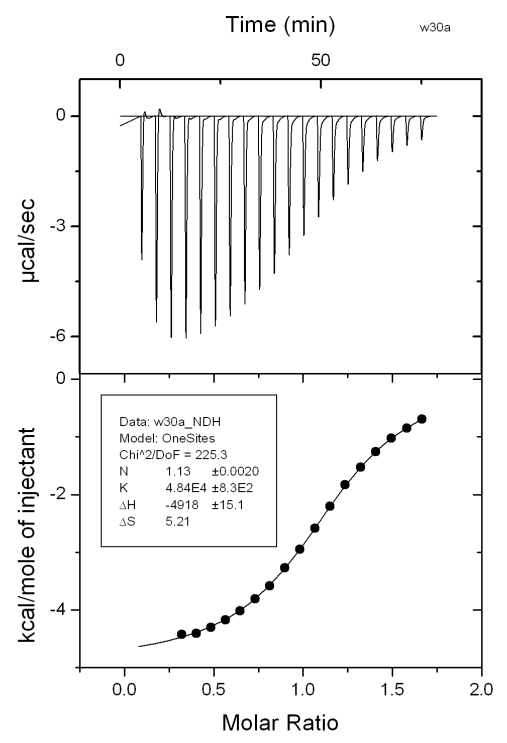


Figure 11. ITC plots of decafluorocalix[5]pyrrole (4) titrated with several anions (TBA salts) at $30^{\circ} \mathrm{C}$

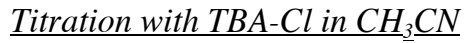

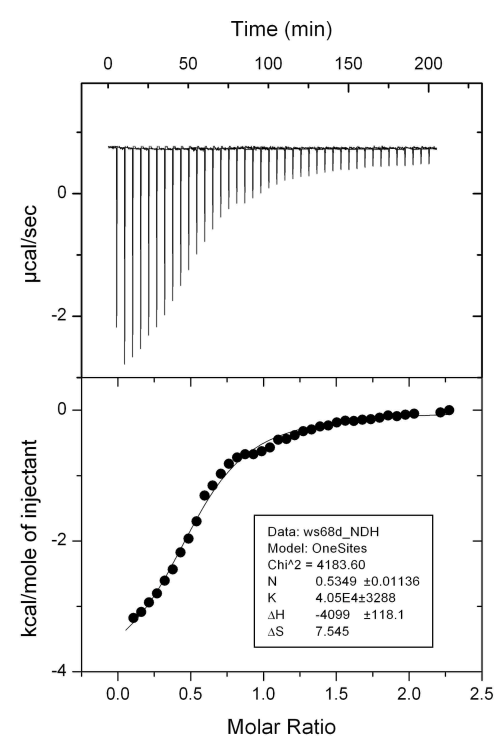

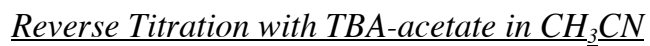

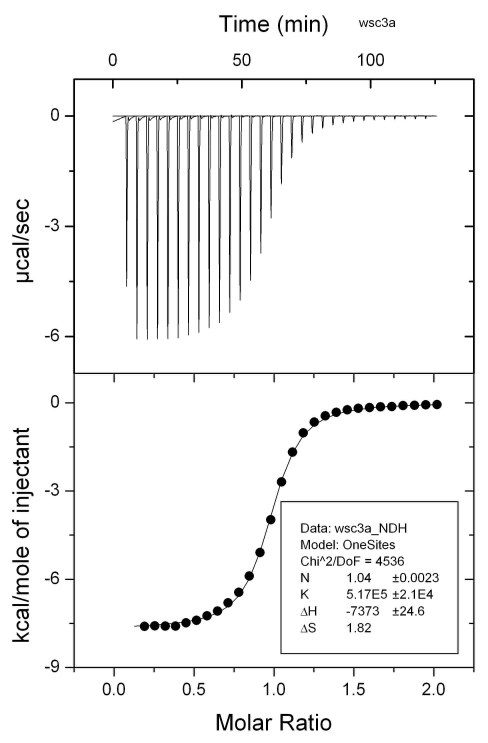

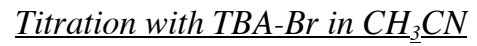

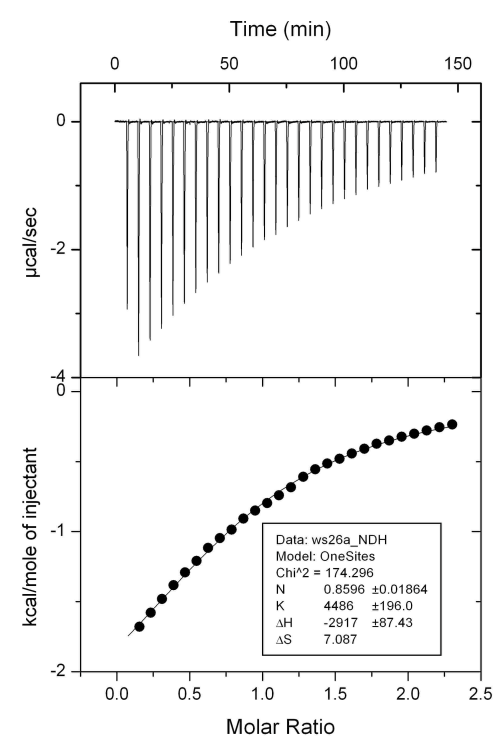

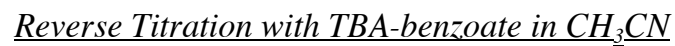

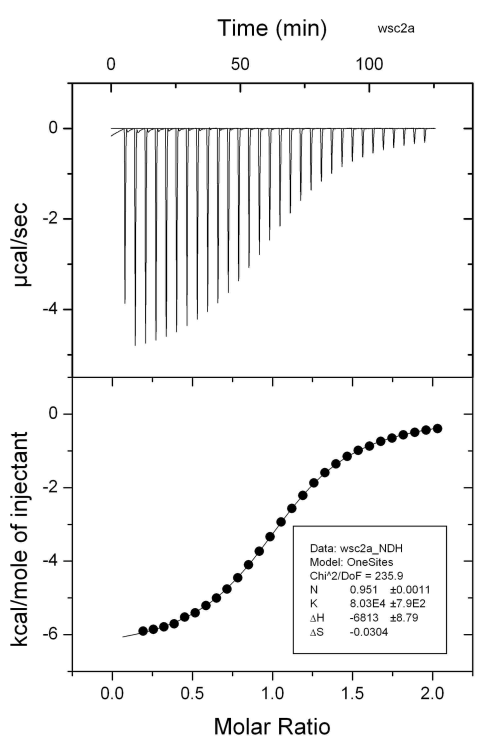



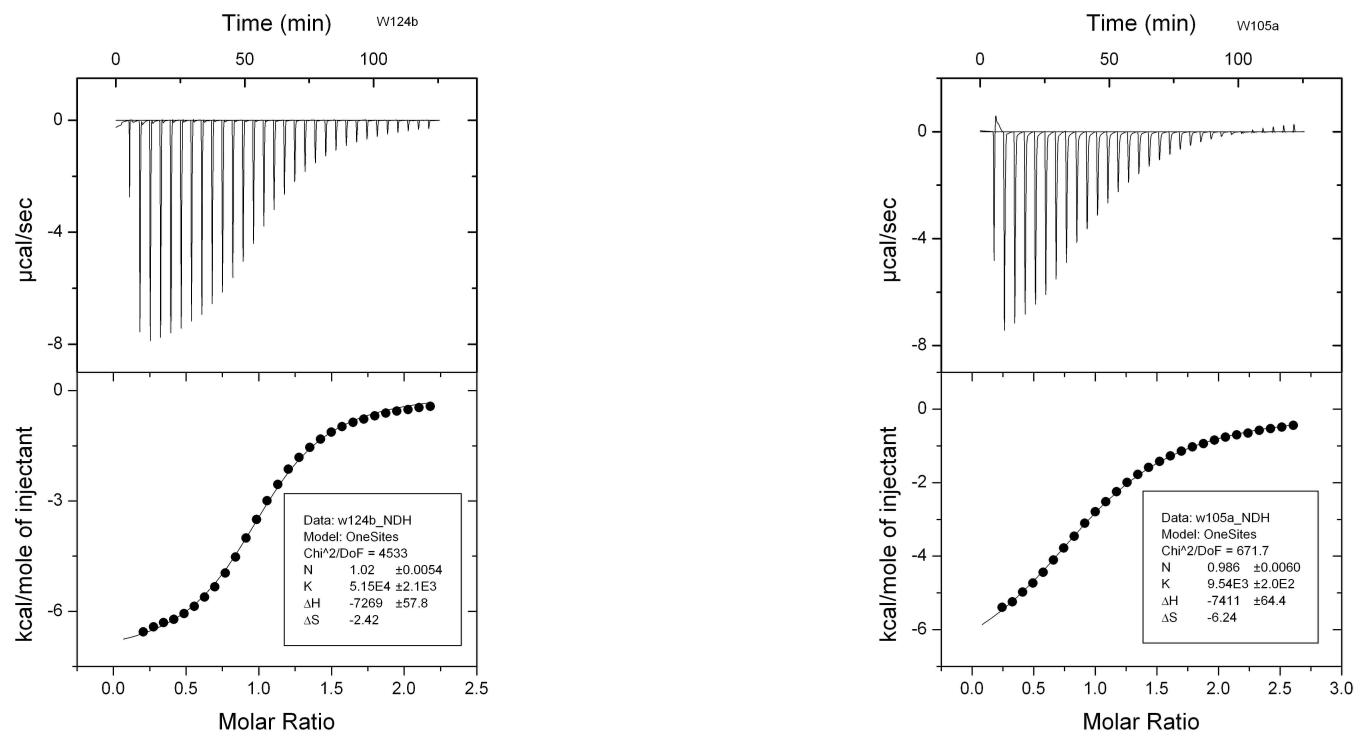

$\underline{\text { Titration with TBA- } \mathrm{H}_{2}}{\underline{P O_{2}}}_{2}$ in DMSO

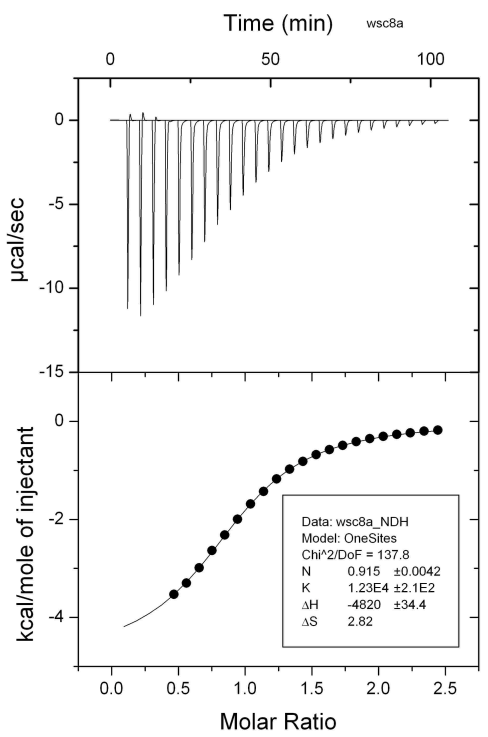


Figure 12. ITC plots of dodecafluorocalix [5]pyrrole (5) titrated with several anions (TBA salts) at $30^{\circ} \mathrm{C}$

Titration with $\mathrm{TBA}-\mathrm{Cl}$ in $\mathrm{CH}_{3} \underline{\mathrm{CN}}$

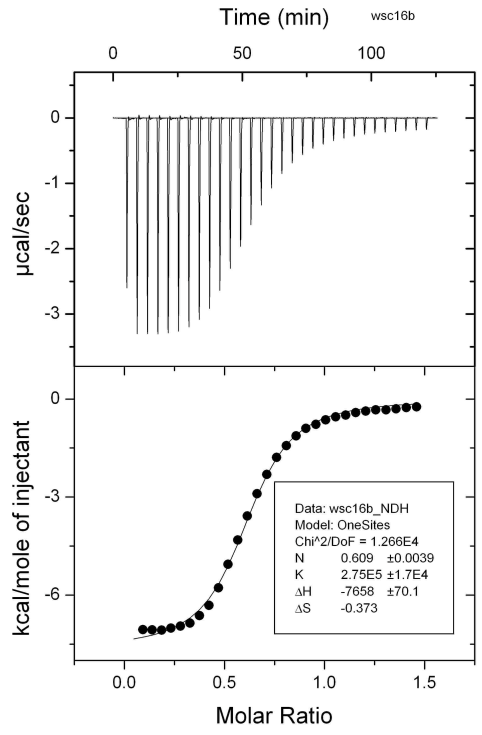

Titration with TBA-I in $\mathrm{CH}_{3} \underline{\underline{C N}}$

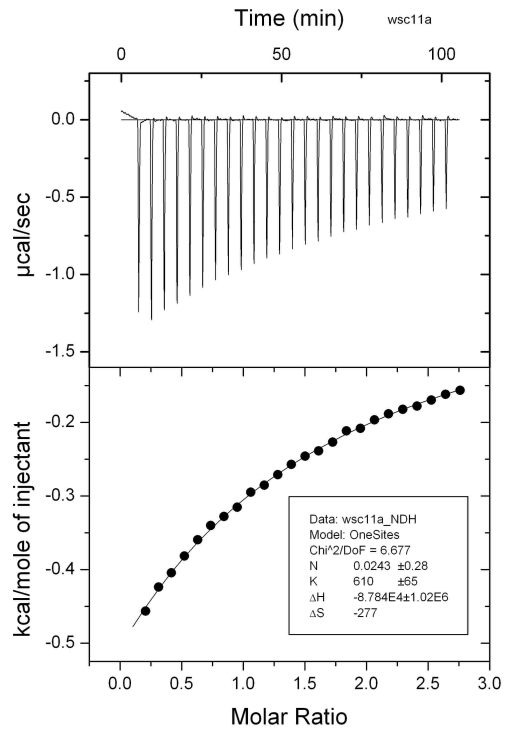

Titration with $\mathrm{TBA}-\mathrm{Br}$ in $\mathrm{CH}_{3} \underline{\mathrm{CN}}$

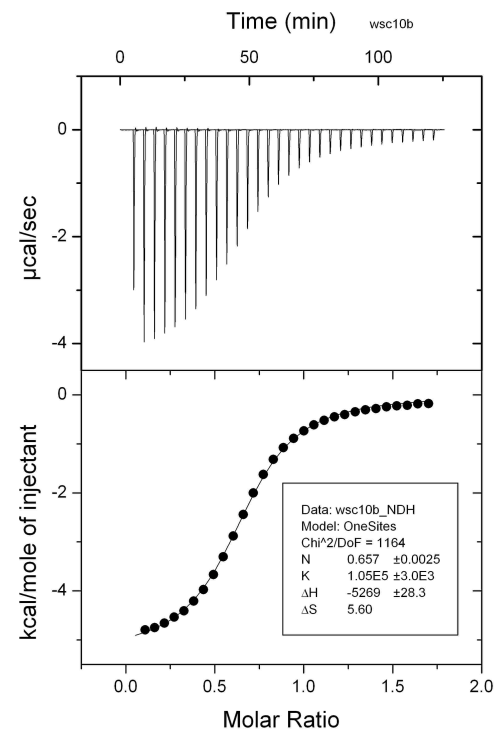

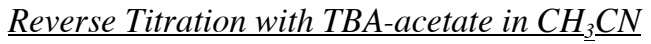

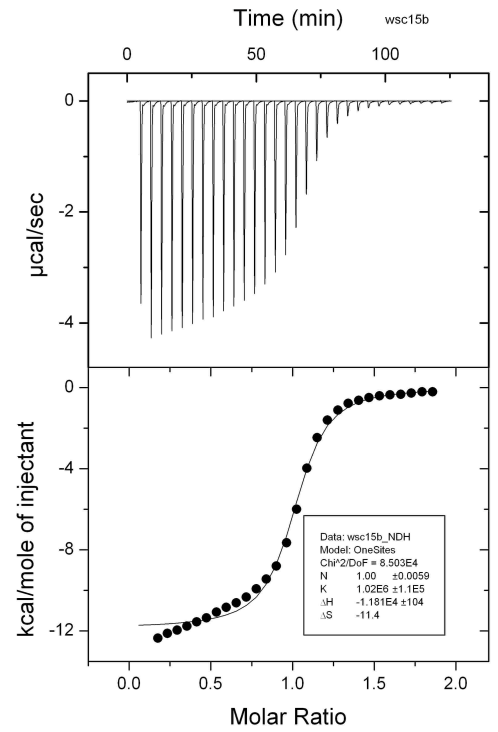



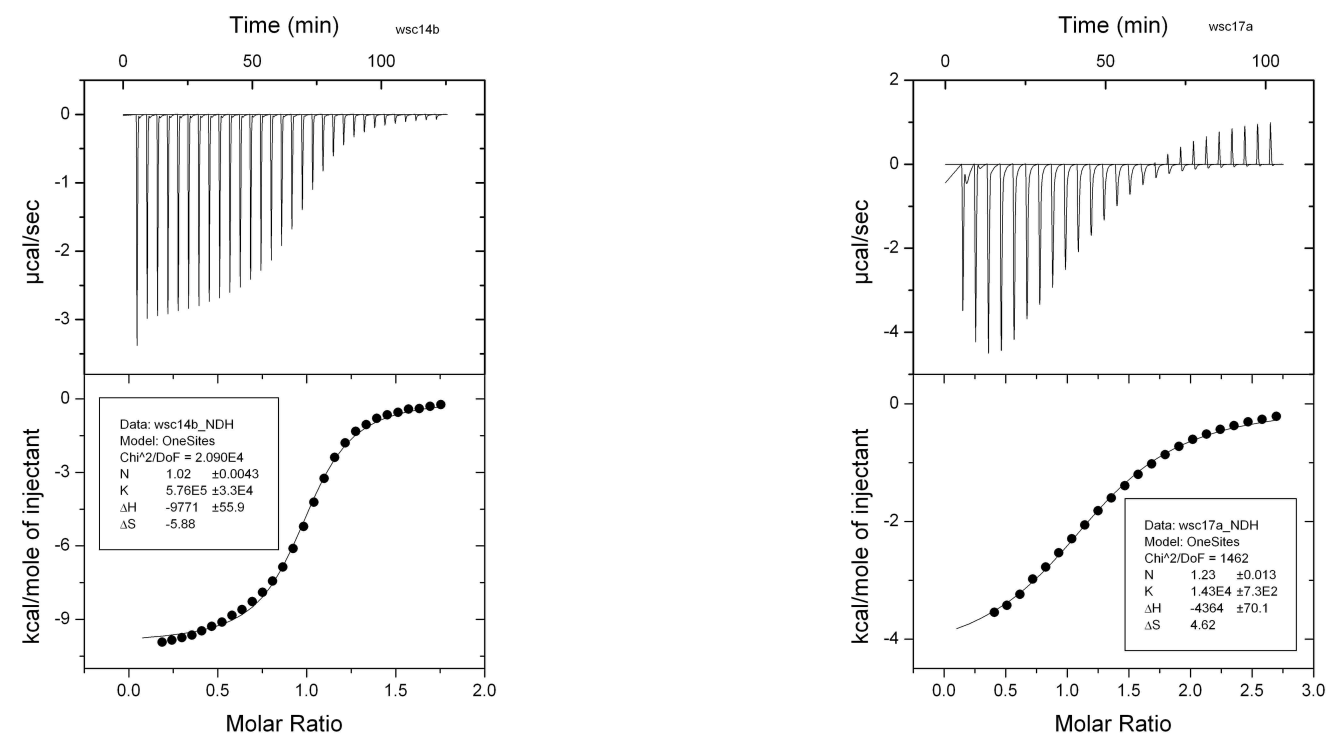

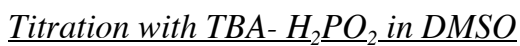

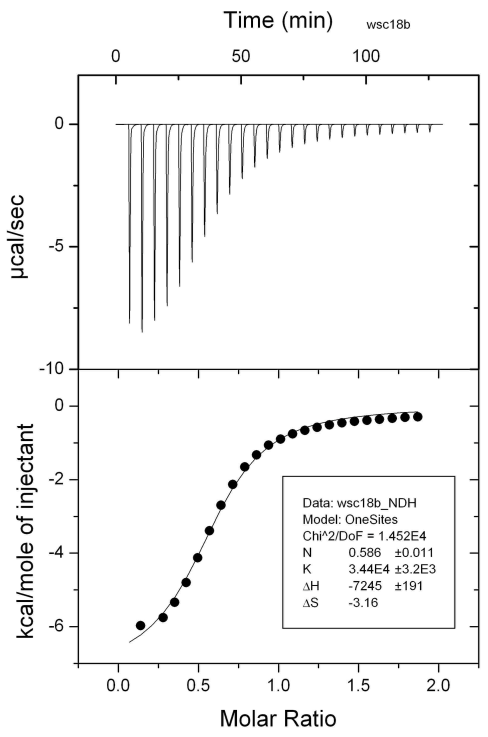




\section{X-ray Experimental Section}

Table 1. Crystal data and structure refinement for $3 \cdot \mathrm{Cl}^{-}$.

Empirical formula

Formula weight

Temperature

Wavelength

Crystal system

Space group

Unit cell dimensions

Volume

Z

Density (calculated)

Absorption coefficient

$\mathrm{F}(000)$

Crystal size

Theta range for data collection

Index ranges

Reflections collected

Independent reflections

Completeness to theta $=27.52^{\circ}$

Absorption correction

Refinement method

Data / restraints / parameters

Goodness-of-fit on $\mathrm{F}^{2}$

Final $\mathrm{R}$ indices [I $>2 \operatorname{sigma}(\mathrm{I})]$

$\mathrm{R}$ indices (all data)

Extinction coefficient

Largest diff. peak and hole

\section{C44 H64 Cl F8 N5}

850.45

153(2) K

$0.71073 \AA$

Triclinic

P-1

$\mathrm{a}=13.6372(2) \AA$

$\alpha=65.928(1)^{\circ}$.

$\mathrm{b}=17.3214(2) \AA$

$\beta=85.442(1)^{\circ}$.

$\mathrm{c}=21.0872(3) \AA$ $\gamma=81.976(1)^{\circ}$.

4502.01(11) $\AA^{3}$

4

$1.255 \mathrm{mg} / \mathrm{m}^{3}$

$0.154 \mathrm{~mm}^{-1}$

1808

$0.47 \times 0.20 \times 0.16 \mathrm{~mm}$

2.99 to $27.52^{\circ}$.

$-16 \leq \mathrm{h} \leq 17,-19 \leq \mathrm{k} \leq 22,-22 \leq 1 \leq 27$

31424

$20555[\mathrm{R}(\mathrm{int})=0.0499]$

$99.0 \%$

None

Full-matrix-block least-squares on $\mathrm{F}^{2}$

20555 / 0 / 1078

1.005

$\mathrm{R} 1=0.0616, \mathrm{wR} 2=0.1060$

$\mathrm{R} 1=0.1732, \mathrm{wR} 2=0.1350$

$7.9(16) \times 10^{-7}$

0.373 and -0.327 e. $\AA^{-3}$ 
Table 2. Hydrogen bonds for $3 \cdot \mathrm{Cl}^{-}\left[\AA\right.$ and $\left.{ }^{\circ}\right]$.

\begin{tabular}{lcccr}
\hline D-H...A & $\mathrm{d}(\mathrm{D}-\mathrm{H})$ & $\mathrm{d}(\mathrm{H} \ldots \mathrm{A})$ & $\mathrm{d}(\mathrm{D} \ldots \mathrm{A})$ & $<(\mathrm{DHA})$ \\
\hline N1-H1N...Cl1 & & & & \\
N2-H2N...Cl1 & $0.87(3)$ & $2.48(3)$ & $3.339(2)$ & $171(3)$ \\
N3-H3N...Cl1 & $0.78(3)$ & $2.52(3)$ & $3.281(3)$ & $168(3)$ \\
N4-H4N...Cl1 & $0.93(3)$ & $2.35(3)$ & $3.277(3)$ & $176(2)$ \\
N1'-H1'N...Cl2 & $0.87(3)$ & $2.48(3)$ & $3.286(3)$ & $153(2)$ \\
N2'-H2'N...Cl2 & $0.87(2)$ & $2.48(3)$ & $3.343(2)$ & $175(2)$ \\
N3'-H3'N...Cl2 & $0.93(3)$ & $2.37(3)$ & $3.289(2)$ & $170(2)$ \\
N4'-H4'N...C12 & $0.88(3)$ & $2.42(3)$ & $3.306(3)$ & $179(3)$ \\
& $0.91(3)$ & $2.41(3)$ & $3.299(2)$ & $166(2)$ \\
\hline
\end{tabular}

X-ray Experimental for $3\left[\left(\mathrm{C}_{28} \mathrm{H}_{28} \mathrm{~N}_{4} \mathrm{~F}_{8}\right) \cdot\left(\mathrm{C}_{16} \mathrm{H}_{36} \mathrm{~N}\right)^{+} \cdot \mathrm{Cl}^{-}\right]$: Crystals grew as large colorless prisms by vapor diffusion of acetone into an ethanol solution of the macrocycle salt. The data crystal was cut from a large crystal and had approximate dimensions; 0.47 $\times 0.20 \times 0.16 \mathrm{~mm}$. The data were collected on a Nonius Kappa CCD diffractometer using a graphite monochromator with MoK $\alpha$ radiation $(\lambda=0.71073 \AA)$. A total of 524 frames of data were collected using $\omega$-scans with a scan range of $1^{\circ}$ and a counting time of 139 seconds per frame. The data were collected at $153 \mathrm{~K}$ using an Oxford Cryostream low temperature device. Details of crystal data, data collection and structure refinement are listed in Table 1. Data reduction were performed using DENZO-SMN. ${ }^{3}$ The structure was solved by direct methods using SIR97 ${ }^{4}$ and refined by full-matrix leastsquares on $\mathrm{F}^{2}$ with anisotropic displacement parameters for the non-H atoms using SHELXL-97. ${ }^{5}$ The hydrogen atoms on carbon were calculated in ideal positions with isotropic displacement parameters set to $1.2 \times$ Ueq of the attached atom $(1.5 \times$ Ueq for methyl hydrogen atoms). The hydrogen atoms bound to the pyrrole nitrogen atoms were observed in a $\Delta F$ map and refined with isotropic displacement parameters.

There are two crystallographically unique salt complexes per asymmetric unit. There are minor comformation differences between the macrocyclic $\mathrm{Cl}$ salts (Figure 13).

The function, $\Sigma \mathrm{w}\left(\left|\mathrm{F}_{\mathrm{O}}\right|^{2}-\left|\mathrm{F}_{\mathrm{c}}\right|^{2}\right)^{2}$, was minimized, where $\mathrm{w}=1 /\left[\left(\sigma\left(\mathrm{F}_{\mathrm{O}}\right)\right)^{2}+(0.0396 \times\right.$ $\left.\mathrm{P})^{2}+(1.3927 \times \mathrm{P})\right]$ and $\mathrm{P}=\left(\left|\mathrm{F}_{\mathrm{o}}\right|^{2}+2\left|\mathrm{~F}_{\mathrm{c}}\right|^{2}\right) / 3 . \mathrm{R}_{\mathrm{w}}\left(\mathrm{F}^{2}\right)$ refined to 0.135 , with $\mathrm{R}(\mathrm{F})$ equal to 
0.0616 and a goodness of fit, $S,=1.00$. Definitions used for calculating $R(F), R_{W}\left(F^{2}\right)$ and the goodness of fit, S, are given below." The data were corrected for secondary extinction effects. The correction takes the form: $\mathrm{F}_{\mathrm{corr}}=\mathrm{kF}_{\mathrm{c}} /\left[1+\left(8(2) \times 10^{-7}\right) \times \mathrm{F}_{\mathrm{c}}{ }^{2}\right.$ $\left.\lambda^{3} /(\sin 2 \theta)\right]^{0.25}$ where $\mathrm{k}$ is the overall scale factor. Neutral atom scattering factors and values used to calculate the linear absorption coefficient are from the International Tables for X-ray Crystallography (1992). ${ }^{6}$

${ }^{\#} \mathrm{R}_{\mathrm{W}}\left(\mathrm{F}^{2}\right)=\left\{\sum \mathrm{w}\left(\left|\mathrm{F}_{\mathrm{O}}\right|^{2}-\left|\mathrm{F}_{\mathrm{C}}\right|^{2}\right)^{2} / \sum \mathrm{w}\left(\left|\mathrm{F}_{\mathrm{O}}\right|\right)^{4}\right\}^{0.5}$ where $\mathrm{w}$ is the weight given each reflection.

$\left.\mathrm{R}(\mathrm{F})=\Sigma\left(\left|\mathrm{F}_{\mathrm{O}}\right|-\left|\mathrm{F}_{\mathrm{C}}\right|\right) / \Sigma\left|\mathrm{F}_{\mathrm{O}}\right|\right\}$ for reflections with $\mathrm{F}_{\mathrm{O}}>4\left(\sigma\left(\mathrm{F}_{\mathrm{O}}\right)\right)$.

$\mathrm{S}=\left[\Sigma \mathrm{w}\left(\left|\mathrm{F}_{\mathrm{O}}\right|^{2}-\left|\mathrm{F}_{\mathrm{C}}\right|^{2}\right)^{2} /(\mathrm{n}-\mathrm{p})\right]^{0.5}$, where $\mathrm{n}$ is the number of reflections and $\mathrm{p}$ is the number of refined parameters. 
Figure 13. View of macrocyclic chloride anion salt 1 in $[3 \cdot \mathrm{Cl}]^{-} \cdot \mathrm{TBA}^{+}$showing the atom labeling scheme. Displacement ellipsoids are scaled to the $50 \%$ probability level. Most hydrogen atoms have been removed for clarity. Dashed lines are indicative of $\mathrm{H}$-bonding interactions. The geometry of these interactions is listed in Table 2.

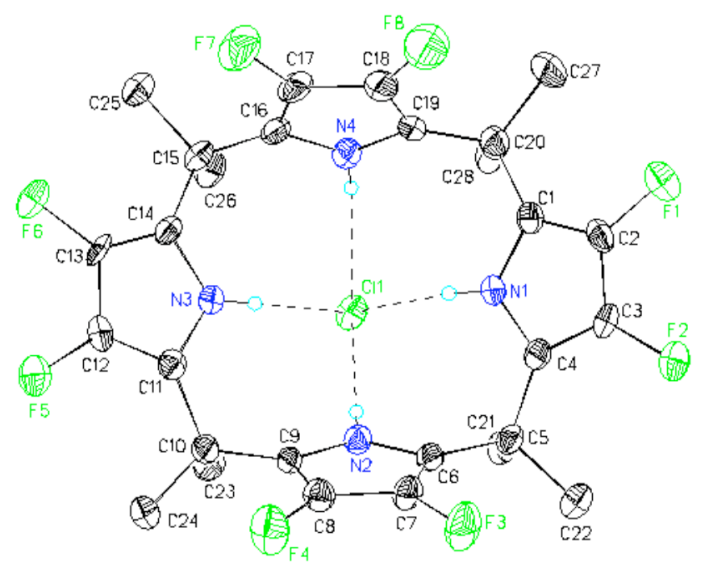

Figure 14. View of the fit by least-squares of the conformation of chloride complex with macrocycle 1 (dashed lines) superimposed on the equivalent atoms of macrocycle 2. The atoms from macrocycle 2 used in the fit are labeled.

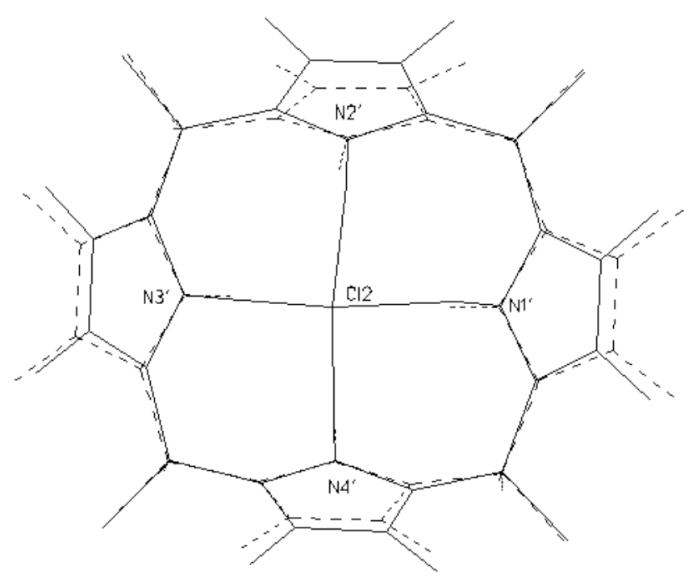


Figure 15. Unit cell packing diagram for $[3 \cdot \mathrm{Cl}]^{-} \mathrm{TBA}^{+}$. The view is approximately down the a axis. Macrocycles 2 are shown in wireframe form and extend in a plane at approximately y $=1 / 2$.

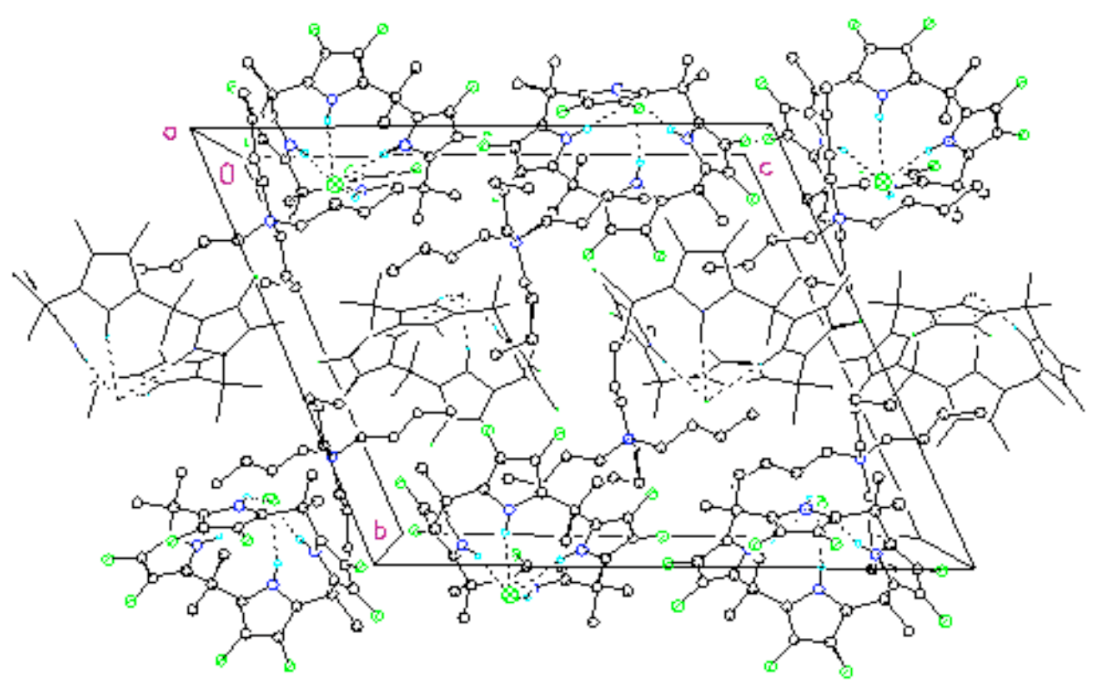


Table 3. Crystal data and structure refinement for $4 \cdot \mathrm{CH}_{3} \mathrm{CO}_{2}$.

Empirical formula

Formula weight

Temperature

Wavelength

Crystal system

Space group

Unit cell dimensions

Volume

Z

Density (calculated)

Absorption coefficient

$\mathrm{F}(000)$

Crystal size

Theta range for data collection

Index ranges

Reflections collected

Independent reflections

Completeness to theta $=27.50^{\circ}$

Absorption correction

Refinement method

Data / restraints / parameters

Goodness-of-fit on $\mathrm{F}^{2}$

Final R indices [I $>2 \operatorname{sigma}(\mathrm{I})]$

$\mathrm{R}$ indices (all data)

Extinction coefficient

Largest diff. peak and hole
C57 H88 F10 N6 O5

1127.33

153(2) K

$0.71073 \AA$

Monoclinic

$\mathrm{P} 21 / \mathrm{n}$

$\mathrm{a}=11.4814(1) \AA$

$\alpha=90^{\circ}$.

$\mathrm{b}=36.1664(5) \AA$

$\beta=99.361(1)^{\circ}$.

$\mathrm{c}=14.6605(2) \AA$

$\gamma=90^{\circ}$.

4

$1.247 \mathrm{mg} / \mathrm{m}^{3}$

$0.100 \mathrm{~mm}^{-1}$

2408

$0.48 \times 0.21 \times 0.20 \mathrm{~mm}$

2.98 to $27.50^{\circ}$.

$-14 \leq \mathrm{h} \leq 14,-44 \leq \mathrm{k} \leq 46,-19 \leq 1 \leq 19$

22182

$13322[\mathrm{R}(\mathrm{int})=0.0445]$

$96.6 \%$

None

Full-matrix least-squares on $\mathrm{F}^{2}$

13322 / 0 / 728

1.244

$\mathrm{R} 1=0.0613, \mathrm{wR} 2=0.1189$

$\mathrm{R} 1=0.1591, \mathrm{wR} 2=0.1313$

$5.1(3) \times 10^{-6}$

0.314 and -0.270 e. $\AA^{-3}$ 
Table 4. Hydrogen bonds for $\mathbf{4} \cdot \mathrm{CH}_{3} \mathrm{CO}_{2}{ }^{-}\left[\AA\right.$ and $\left.{ }^{\circ}\right]$.

\begin{tabular}{lcccc}
\hline D-H...A & $\mathrm{d}(\mathrm{D}-\mathrm{H})$ & $\mathrm{d}(\mathrm{H} \ldots \mathrm{A})$ & $\mathrm{d}(\mathrm{D} \ldots \mathrm{A})$ & $<(\mathrm{DHA})$ \\
\hline N1-H1N...O2B & $0.89(2)$ & $1.94(2)$ & $2.824(3)$ & $174(2)$ \\
N5-H5N...O2B & $0.85(3)$ & $2.08(3)$ & $2.854(3)$ & $150(2)$ \\
N4-H4N...O1W & $0.88(2)$ & $2.05(2)$ & $2.858(3)$ & $153.2(19)$ \\
O1W-H1WA...O2B & $1.07(5)$ & $1.75(5)$ & $2.818(3)$ & $176(4)$ \\
N3-H3N...O1W & $0.82(2)$ & $2.04(2)$ & $2.856(3)$ & $171(2)$ \\
N2-H2N...O1B & 0.90 & 2.20 & $3.026(3)$ & 153.1 \\
O1W-H1WB...O1E & $0.75(4)$ & $1.92(4)$ & $2.648(12)$ & $162(4)$ \\
O1W-H1WB...O1EA & $0.75(4)$ & $2.09(4)$ & $2.826(13)$ & $167(4)$ \\
& & & &
\end{tabular}

X-ray Experimental for $4\left[\left(\mathrm{C}_{35} \mathrm{H}_{35} \mathrm{~N}_{5} \mathrm{~F}_{10}\right) \cdot\left(\mathrm{C}_{16} \mathrm{H}_{36} \mathrm{~N}\right)^{+} \cdot \mathrm{C}_{2} \mathrm{H}_{3} \mathrm{O}_{2} \cdot 2 \mathrm{C}_{2} \mathrm{H}_{5} \mathrm{OH} \cdot \mathrm{H}_{2} \mathrm{O}\right]$ : Crystals grew as long colorless needles from ethanol and methylene chloride. The data crystal was cut from a very long needle and had approximate dimensions; $0.48 \times 0.21 \times$ $0.20 \mathrm{~mm}$. The data were collected on a Nonius Kappa CCD diffractometer using a graphite monochromator with $\operatorname{MoK} \alpha$ radiation $(\lambda=0.71073 \AA)$. A total of 513 frames of data were collected using $\omega$-scans with a scan range of $1^{\circ}$ and a counting time of 117 seconds per frame. The data were collected at $153 \mathrm{~K}$ using an Oxford Cryostream low temperature device. Details of crystal data, data collection and structure refinement are listed in Table 3. Data reduction were performed using DENZO-SMN. ${ }^{3}$ The structure was solved by direct methods using SIR $97^{4}$ and refined by full-matrix least-squares on $\mathrm{F}^{2}$ with anisotropic displacement parameters for the non-H atoms using SHELXL-97. ${ }^{5}$ The hydrogen atoms on carbon were calculated in ideal positions with isotropic displacement parameters set to $1.2 \times$ Ueq of the attached atom $(1.5 \times$ Ueq for methyl hydrogen atoms $)$. The hydrogen atoms on the pyrrole nitrogen atoms and the water molecule were observed from a $\Delta \mathrm{F}$ map and refined with isotropic displacement parameters. The hydrogen atom on $\mathrm{N} 2$ did not refine well and was calculated in an ideal position with Uiso set to $1.2 \times$ Ueq of N2. 
The two ethanol molecules were disordered. One molecule could be modeled satisfactorily but the second ethanol molecule could not. The first ethanol molecule was modeled by refining the site occupancy factors for the two orientations so that the sum equaled unity. While refining the site occupancy factors, a common isotropic displacement parameter was refined. Additionally, the geometry of the two components was restrained to be approximately equal throughout the refinement process. The site occupancy factors refined to a value very close to $1 / 2$. The site occupancy factor was set to $1 / 2$ for the two components.

The refinement of the second ethanol molecule was attempted in the same fashion. However, a realistic model was never obtained. Therefore, the utility SQUEEZE in PLATON98 ${ }^{7}$ in $\mathrm{WinGX}^{8}$ was used to remove the solvent contributions to the scattering.

The function, $\Sigma \mathrm{w}\left(\left|\mathrm{F}_{\mathrm{O}}\right|^{2}-\left|\mathrm{F}_{\mathrm{c}}\right|^{2}\right)^{2}$, was minimized, where $\mathrm{w}=1 /\left[\left(\sigma\left(\mathrm{F}_{\mathrm{O}}\right)\right)^{2}+(0.036 \times\right.$ $\left.\mathrm{P})^{2}\right]$ and $\mathrm{P}=\left(\left|\mathrm{F}_{\mathrm{o}}\right|^{2}+2\left|\mathrm{~F}_{\mathrm{c}}\right|^{2}\right) / 3 . \quad \mathrm{R}_{\mathrm{W}}\left(\mathrm{F}^{2}\right)$ refined to 0.131 , with $\mathrm{R}(\mathrm{F})$ equal to 0.0613 and $\mathrm{a}$ goodness of fit, $\mathrm{S},=1.24$. Definitions used for calculating $\mathrm{R}(\mathrm{F}), \mathrm{R}_{\mathrm{W}}\left(\mathrm{F}^{2}\right)$ and the goodness of fit, S, are given below. ${ }^{\#}$ The data were corrected for secondary extinction effects. The correction takes the form: $F_{c o r r}=\mathrm{kF}_{\mathrm{c}} /\left[1+\left(5.1(3) \times 10^{-6}\right) \times \mathrm{F}_{\mathrm{c}}{ }^{2} \lambda^{3} /(\sin 2 \theta)\right]^{0.25}$ where $\mathrm{k}$ is the overall scale factor. Neutral atom scattering factors and values used to calculate the linear absorption coefficient are from the International Tables for X-ray Crystallography (1992). ${ }^{6}$

${ }^{\#} \mathrm{R}_{\mathrm{W}}\left(\mathrm{F}^{2}\right)=\left\{\Sigma \mathrm{w}\left(\left|\mathrm{F}_{\mathrm{O}}\right|^{2}-\left|\mathrm{F}_{\mathrm{C}}\right|^{2}\right)^{2} / \Sigma \mathrm{w}\left(\left|\mathrm{F}_{\mathrm{O}}\right|\right)^{4}\right\}^{0.5}$ where $\mathrm{w}$ is the weight given each reflection.

$\left.\mathrm{R}(\mathrm{F})=\Sigma\left(\left|\mathrm{F}_{\mathrm{O}}\right|-\left|\mathrm{F}_{\mathrm{C}}\right|\right) / \Sigma\left|\mathrm{F}_{\mathrm{O}}\right|\right\}$ for reflections with $\mathrm{F}_{\mathrm{O}}>4\left(\sigma\left(\mathrm{F}_{\mathrm{O}}\right)\right)$. $\mathrm{S}=\left[\Sigma \mathrm{w}\left(\left|\mathrm{F}_{\mathrm{O}}\right|^{2}-\left|\mathrm{F}_{\mathrm{C}}\right|^{2}\right)^{2} /(\mathrm{n}-\mathrm{p})\right]^{0.5}$, where $\mathrm{n}$ is the number of reflections and $\mathrm{p}$ is the number of refined parameters. 
Figure 16. View of the macrocycle present in $\left[4 \cdot \mathrm{CH}_{3} \mathrm{CO}_{2}\right]^{-} \cdot \mathrm{TBA}^{+}$showing the atom labeling scheme. Displacement ellipsoids are scaled to the $50 \%$ probability level.

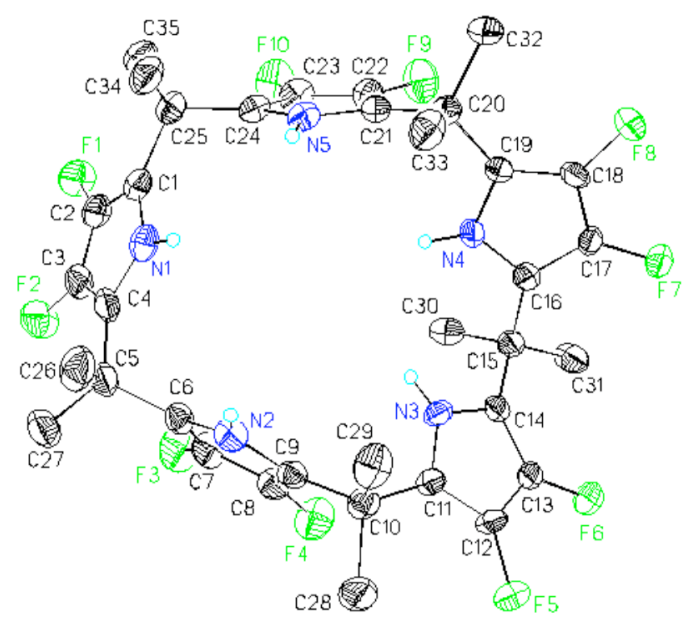

Figure 17. View illustrating the $\mathrm{H}$-bonding interactions in $\left[4 \cdot \mathrm{CH}_{3} \mathrm{CO}_{2}\right]^{-} \cdot \mathrm{TBA}^{+}$. Displacement ellipsoids are scaled to the $50 \%$ probability level. Most hydrogen atoms have been removed for clarity. Dashed lines are indicative of $\mathrm{H}$-bonding interactions. The geometry of these interactions are listed in Table 4. Only the major component of the disordered ethanol molecule is shown.

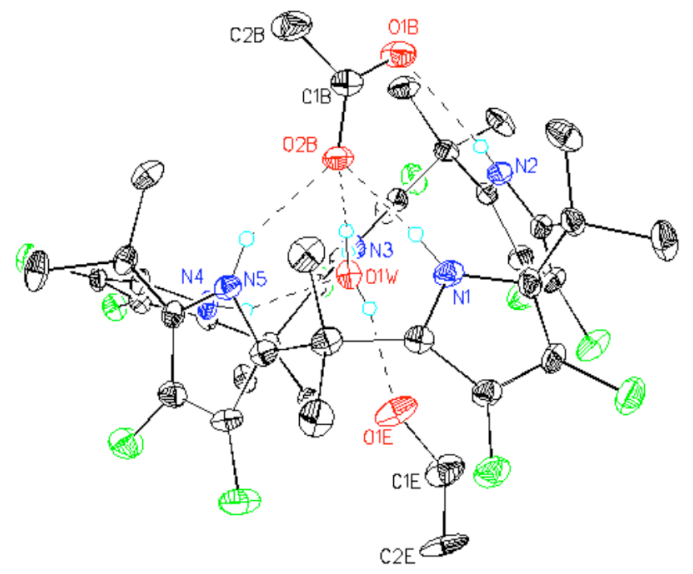


Figure 18. Unit cell packing diagram for $\left[4 \cdot \mathrm{CH}_{3} \mathrm{CO}_{2}\right]^{-} \cdot \mathrm{TBA}^{+}$. The view is approximately down the a axis.

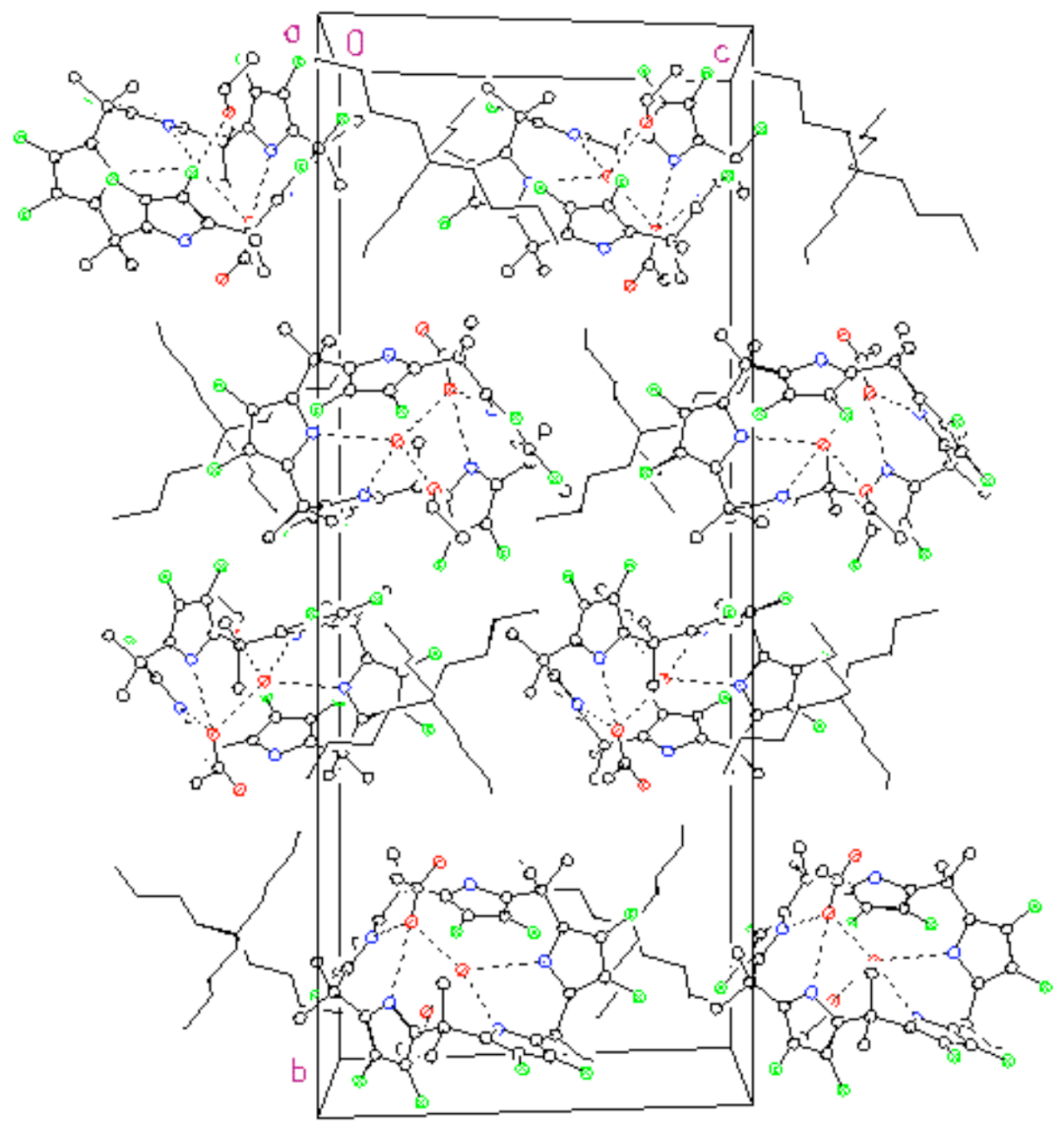




\section{References}

(1) Anzenbacher, P., Jr.; Try, A. C.; Miyaji, H.; Jursíková, K.; Lynch, V. M.; Marquez, M.; Sessler, J. L. J. Am. Chem. Soc. 2000, 122, 10268; Sessler, J. L.; Anzenbacher, P., Jr.; Shriver, J. A.; Jursíková, K.; Lynch, V. M.; Marquez, M. J. Am. Chem. Soc. 2000, $122,12061$.

(2) Wilcox, C. S., In Frontiers in Supramolecular Organic Chemistry and Photochemistry, Schneider, H.-J., Dürr, H., Eds. VCH: Weinheim, 1991, 123.

(3) Otwinowski, Z.; Monor, W., Macromolecular Crystallography, Part A. In Method in Enzymology, Carter, C. W., Jr, Sweets, R. M., Eds. Acedemic Press: 1997, 307.

(4) Altomare, A.; Burla, M. C.; Camalli, M.; Cascarano, G. L.; Giacovazzo, C.; Guagliardi, A.; Moliterni, A. G. G.; Polidori, G.; Spagna, R. J. Appl. Cryst. 1999, 32, 115.

(5) Sheldrick, G. M. Program for the Refinement of Crystal Structures., University of Gottingen, Germany: 1994.

(6) Internation Tables for X-ray Crystallography; Wilson, J. C., Eds.; Kluwer Academic Press: Boston, 1992.

(7) Spek, A. L. PLATON, A Multipurpose Crystallographic Tool, Utrecht University: Netherlands, 1998.

(8) Farrugia, L. J. J. Appl. Cryst. 1999, 32, 837. 